\title{
Spotlight turns on blood policy advisers
}

Tokyo. Now that Japan's haemophiliacs have reached a settlement with the government and pharmaceutical companies over their infection with HIV by blood coagulants (see Nature 380, 278; 1996), attention has switched to investigation of possible criminal charges against individuals responsible for setting policy on blood products in the early to mid-1980s.

Shortly before the settlement was reached late last month, the Tokyo District Prosecutor's Office announced that it had set up a team of six prosecutors to investigate possible criminal charges. Chief among those to be investigated is Takeshi Abe, who headed an AIDS study group set up by the ministry in June 1983. Abe advocated the continued use of non-heat-treated concentrates of blood coagulants, and insisted on clinical trials for heattreated products, a process that under Abe's direction took nearly two years.

Abe's position won the day over those of others in the ministry and the study

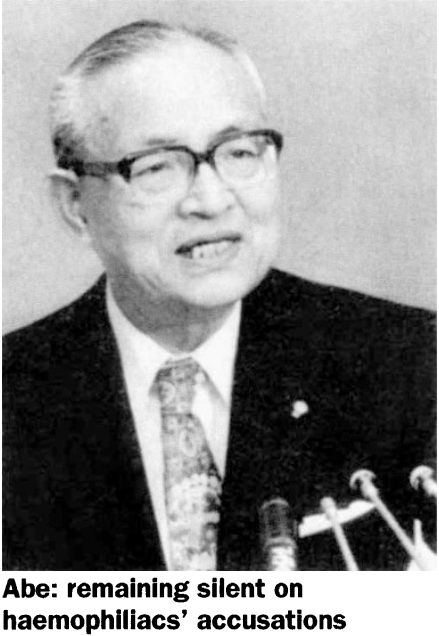

adverse publicity surrounding him, flatly denies any connection between his fundraising and his decision-making as head of the AIDS study group and coordinator of the clinical trials of heat-treated products.

The allegations made against him, however, relate to a different matter. In 1994, a group of haemophiliacs filed charges with the Tokyo prosecutor's office of "wilful negligence resulting in death" (see Nature 368, 680 ; 1994). Similarly, earlier this year the mother of a haemophiliac patient of Abe's who had died of AIDS filed charges of murder against him (see Nature 379, 664; 1996).

The haemophiliacs claim that Abe continued to administer non-heattreated products to his patients in 1985, even although he knew there was a high possibility of infection with HIV. As evidence, they point out that, in late 1984, Abe received results from Robert Gallo's laboratory in the United States which showed that 23 out of 48 patients under Abe's care group who had suggested various alternatives, including emergency imports of heattreated products, a ban on the imports of non-heat-treated blood products, and a return to the use of cryoprecipitate, a blood coagulant which, unlike concentrates, is obtained from a small number of donors.

Abe has come under severe attack by the Japanese media because, immediately before being appointed head of the AIDS study group, he had started to solicit large donations from blood product manufacturers for a foundation he wanted to set up. There have also been allegations that he continued to seek money from blood product manufacturers while he was coordinating clinical trials of heat-treated products for the companies between 1984 and 1985.

Atsuaki Gunji, a former ministry official who set up the AIDS study group, told Nature in 1988 that he received "many complaints" about Abe's fund-raising activities. At the time, Abe denied that he had used his influence to delay the introduction of heattreated products. But there have recently been widespread suggestions in the Japanese media that Abe may have done so, in order to enable Japanese manufacturers which were behind in the development of heat-treated products - in particular Midori Juji (Green Cross Corporation) of Osaka - to catch up with US and European manufacturers.

Abe, who recently resigned as vice president of Teikyo University because of were already infected with HIV. They also cite a paper published by Abe which shows that some of his patients became HIV-positive only in 1985 .

Furthermore, they claim that there is evidence that Abe should have been aware of the dangers long before this. Abe had a haemophiliac patient who died of classic AIDS symptoms in July 1983, and this is now widely believed to be Japan's first AIDS patient. But in 1983, Abe's colleagues in the AIDS study group and the Ministry of Health and Welfare did not recognize the patient as an AIDS victim - despite the fact that a US expert had told Abe and ministry officials that the patient was almost certainly an AIDS sufferer.

When the allegations were made in 1994, Abe refused to comment on them, saying he had been instructed to remain silent by the prosecutors office. The office is also planning to investigate an accusation of perjury that has been filed by a group of haemophiliacs against Gunji. They claim that Gunji gave false testimony in the Tokyo court case when he had said that he was unaware of the similarity of infection routes for HIV and hepatitis B.

The Ministry of Health and Welfare recently released another report on its internal investigation into the blood scandal. But the report has only created confusion, rather than clarifying the decision-making process that took place in 1983 .

Three members of the AIDS study group told ministry officials they remember that, at the time the study group was set up in June 1983, Gunji suggested that heat-treated products could be imported on an emergency basis. In particular, Yuichi Shiokawa, who subsequently headed the ministry's AIDS committee after Abe, says he was surprised by Gunji's suggestion because it showed how seriously the ministry was viewing the matter.

But other members of the study group, including Abe, say they have no recollection of Gunji suggesting emergency imports. And Gunji himself says that emergency imports were only informally discussed by ministry officials as one of many options, and were not formally considered by the study group.

However, other documents released by the ministry show that a subcommittee of the AIDS study group, headed by Mutsuyoshi Kazama of Teikyo University, discussed emergency imports of heat-treated products at its first meeting on 14 September 1983 , but dismissed the idea and insisted on clinical trials of heat treated products. According to Kazama's notes of the meeting, Gunji also asked them to consider a reversion to use of cyroprecipitate. But this idea was also rejected.

The ministry has made no attempt to determine who is telling the truth about the discussion of emergency imports, nor has it provided an explanation of why the idea was dropped. Rather, it has simply released a set of contradictory statements. Haemophiliacs are now calling for an independent investigation, by, for example, the Japanese Diet (parliament).

In addition to the accusations against Abe and Gunji, prosecutors in Osaka will investigate a charge of murder that has been filed against a former president of Green Cross Corporation. The accusation has been made by the relatives of a non-haemophiliac who died of AIDS after receiving non-heattreated blood products in April 1986 for treatment of liver disease.

They claim that Renzo Matsushita, president of the company for five years after heading the ministry of health's Pharmaceutical Bureau, "shipped the products for profits, knowing that patients who received the products will contract HIV and die".

During the course of the ministry's investigations of the blood scandal, it has been established that Green Cross Corporation gave false statements to the ministry about the time of its withdrawal of non-heattreated products.

The company claimed to have withdrawn all non-heat-treated products by May 1986, but it did not in fact complete withdrawal until April 1988. Furthermore, it continued to supply non-heat-treated products to hospitals well into 1986, months after it claimed to have stopped.

David Swinbanks 